\title{
Monitoring of Five Different Insecticide Resistance Status in Turkish House Fly Musca domestica L. (Diptera: Muscidae) Populations and the Relationship Between Resistance and Insecticide Usage Profile
}

\author{
Türkiye Karasinek Musca domestica L. Populasyonlarının Beş Farklı İnsektisite Karşı Direnç \\ Durumunun İzlenmesi ve Direncin İnsektisit Kullanım Profiliyle İlişkisi
}

\author{
Muhammet Mustafa Akıner ${ }^{1}$, Selim Sualp Çağlar² \\ 'Department of Biology, Faculty of Arts and Sciences, Recep Tayyip Erdoğan University, Rize, Turkey \\ 2Department of Biology, Faculty of Sciences, Hacettepe University, Ankara, Turkey
}

\begin{abstract}
Objective: The objective of this study is to assess the resistance status and yearly changes involved for house fly populations from six cities in Turkey.

Methods: Field strains of house fly (Musca domestica L. Diptera: Muscidae) were collected in 2004-2006 from cow farms (Antalya, İmir) and garbage dumps (Adana, Ankara, İstanbul, Şanlıurfa) in Turkey. The resistance levels of first and two generation offspring were determined against five insecticides (cypermethrin, cyphenothrin, deltamethrin, permethrin and fenitrothion).

Results: While the highest resistance level for pyrethroid was determined for Antalya 2005 strain (851.97 Cypermethrin) and lowest resistance level for Şanlıurfa 2004 strain (2.06 Permethrin), the highest fenitrothion resistance was found in Şanlıurfa 2004 strain (50.37) and lowest fenitrothion resistance was found in Adana 2004 strain (6.45).

Conclusion: Our results showed that pyrethroid resistance levels were very high and determined a decreasing trend for Antalya and Istanbul strains and an increasing trend for Adana and Şanlıurfa strain for all tested pyrethroid insecticides from 2004 to 2006 . Although cypermethrin and cyphenothrin resistance showed a decreasing trend, deltamethrin and permethrin showed an increasing trend for the lzmir strain from 2004 to 2006. The same trend was also determined for the Ankara strain except for permethrin. Fenitrothion resistance was determined to be lower than pyrethroids, but these levels were still high. Flies from cow farms were generally more resistant than those from garbage dumps. Our results also revealed the presence of strong selective pressure on the populations. (Turkiye Parazitol Derg 2012; 36: 87-91)
\end{abstract}

Key Words: Musca domestica L., insecticide resistance, monitoring, pyrethroid, organophosphate

Received: 30.11 .2011

Accepted: 23.02 .2012

\section{ÖZET}

Amaç: Bu çalışmanın amacı Türkiyenin altı ilinden getirilen karasinek soylarında direnç durumunun ve yıllık değişiminin saptanmasıdır. Yöntemler: Karasineklerin (Musca domestica L. Diptera: Muscidae) alan soyları 2004 ve 2006 yılları arasında Türkiye'de bulunan inek çiftlikleri (Antalya, İzmir) ve çöp depolama alanlarından (Adana, Ankara, Şanlıurfa, İstanbul) toplanmıştır. Alan soylarından laboratuvarda elde edilen birinci ve ikinci kuşak bireylerinin 5 farklı insektisite karşı (cypermethrin, cyphenothrin, deltamethrin, permethrin and fenitrothion) direnç seviyeleri tespit edilmiştir.

Bulgular: En yüksek pyrethroid direnci Antalya 2005 soyunda (851.97 Cypermethrin) ve en düşük pyrethroid direnci Şanlıurfa 2004 soyunda (2.06 Permethrin) tespit edilirken, en yüksek fenitrothion direnci Şanlıurfa 2004 soyunda (50.37), en düşük fenitrothion direnci Adana 2004 soyunda (6.45) bulunmuştur.

Address for Correspondence / Yazışma Adresi: Dr. Muhammet Mustafa Akıner, Department of Biology, Faculty of Arts and Sciences, Recep Tayyip Erdoğan University, Rize, Turkey Phone: +90 46422361 26/1834 E-mail: akiner.m@gmail.com doi:10.5152/tpd.2012.21 
Sonuç: Bizim sonuçlarımız pyrethroid direnç seviyesinin yüksek olduğunu, denenmiş olan pyrtehroidler için 2004-2006 yılları arasında Antalya ve İstanbul soylarında azalış, Adana ve Şanlıurfa soylarında artış trendinde olduğunu göstermiştir. İzmir soyunda $2004-2006$ yılları arasında cypermethrin ve cyphenothrin direnci azalış trendi göstermiş olsa da deltamethrin ve permethrin direnci artış trendi göstermiştir. Aynı trend permethrin hariç Ankara soyu içinde tanımlanmıştır. Fenitrothion direnci pyrethroid direncinden düşük bulunmuştur fakat bu seviye hala yüksektir. Inek ahırlarından gelen soylar çöplüklerden gelen soylardan daha fazla dirençlidir. Bizim sonuçlarımız aynı zamanda popülasyonlar üzerinde yoğun bir seçilim baskısı olduğunu göstermiştir. (Turkiye Parazitol Derg 2012; 36: 87-91)

Anahtar Sözcükler: Musca domestica L., insektisit direnci, izleme, pyrethroid, organofosfat

\section{INTRODUCTION}

The house fly, Musca domestica L. (Diptera: Muscidae) is a major pest for human and domesticated animals. It is a potential vector of many different diseases such as dysentery, typhoid, trachoma and cutaneous diphtheria $(1,2)$. Insecticide resistance has developed within all populations of $M$. domestica $L$. around the world, causing an important problem for house fly control $(3,4)$. There are many studies from around the world showing that flies in houses and animal shelters can develop high resistance to organochlorines, organophosphates, carbamates, and synthetic pyrethroids (5-12). Periodical or continuous evaluation of the resistance status of local populations of $M$. domestica to different insecticides can yield information about suitable usage of insecticides. Therefore, it is necessary to assess the resistance status of $M$. domestica continuously for development of effective and realistic control programs that can minimize insecticide resistance.

The objective of this study is to assess the resistance status and yearly changes involved for house fly populations from six cities in Turkey. Our goals were to survey the resistance levels of $M$. domestica populations which will help in understanding the direction of resistance for future monitoring efforts.

\section{METHODS}

\section{Insects}

House fly samples were collected by sweep net in 2004-2006 from six cities in Turkey. These areas were cow farms in Antalya and Izmir and garbage dumps in Adana, Ankara, İstanbul, and Şanlıurfa. GPS coordinates; brief descriptions and insecticide usage of locations are provided in Table 1. The flies were colonized at the insectary in Hacettepe University Ecological Sciences Research Laboratory (ESRL). Flies were reared at $27 \pm 1^{\circ} \mathrm{C}$ and $65 \%$ relative humidity with a $12-\mathrm{h}$ photoperiod. Collected female house flies were then left to lay eggs. Eggs were inoculated in larval medium $500 \mathrm{~g}$ wheat bran, $120 \mathrm{~g}$ powdered milk and 500 $\mathrm{ml}$ of water. Flies were bioassayed, beginning with the first generation of field-collected flies. The World Health Organization (WHO) standardized-insecticide susceptible reference strain was obtained from Danish Pests Infestation Laboratory as a control strain.

\section{Insecticides}

Five technical-grade insecticides were tested and each insecticide was diluted five times with analytical-grade acetone. All technical grade insecticides were obtained from the Hacettepe University Insecticide Tests and Production Laboratory. These were Cypermethrin (94\%), Permethrin (96\% cis-trans 25-75) (Changzhou, China), Cyphenothrin (93\%) (Sumitomo Chem. Co), Deltamethrin (99.6\%), (Aventis CropScience), Fenitrothion (99\%) (United Phosphorus Ltd). Although many pyrethroid group insecticides are used in house fly control, usage rates of these insecticides (Cypermethrin, Permethrin, Cyphenothrin, Deltamethrin) are very high in Turkey. Fenitrothion was used for mosquito and house fly control in the 1990s but this insecticide usage is very limited in the 2000s in Turkey. Therefore we aimed to determine the resistance direction after give up usage insecticide.

Table 1. GPS coordinates, usage of insecticides in the last 10 years for vector control and application dosages of collected populations

\begin{tabular}{|c|c|c|c|c|c|c|}
\hline Area & GPS coordinates & Location & Area type & \multicolumn{3}{|c|}{ Insecticide usage profile years from 1997 to 2006} \\
\hline Ankara & $3952^{\prime}$ N 32 55' E & Mamak & Garbage & \multicolumn{3}{|c|}{ Azametiphos, Chlorpyriphos methyl, Cypermethrin, } \\
\hline Antalya & $3652^{\prime} \mathrm{N} 3054^{\prime} \mathrm{E}$ & Kundu & Cow farm & \multicolumn{3}{|c|}{ Azametiphos, Cyfluthrin, Resmethrin, Cyromazine (IGR) } \\
\hline İstanbul & $4103^{\prime}$ N $2856^{\prime} E$ & Sutluce & Garbage & \multicolumn{3}{|c|}{ Resmethrin, Methoprene (IGR) } \\
\hline İzmir & 38 27’ N $2713^{\prime} \mathrm{E}$ & Bornova & Cow farm & Cyphenothrin, D & methrin, Permeth & Resmethrin \\
\hline \multirow[t]{2}{*}{ Şanlıurfa } & \multirow[t]{2}{*}{$3706^{\prime} \mathrm{N} 3848^{\prime} \mathrm{E}$} & \multirow[t]{2}{*}{ Yenice } & \multirow[t]{2}{*}{ Garbage } & \multicolumn{3}{|c|}{ Azametiphos, Cyfluthrin, Cypermethrin, Cyphenothrin, } \\
\hline & & & & \multicolumn{3}{|c|}{ Deltamethrin, Primiphos methyl, Zeta-cypermethrin } \\
\hline \multicolumn{2}{|c|}{$\begin{array}{l}\text { Insecticides } \\
\text { Maximum Application Doses }\end{array}$} & Cypermethrin & Cyphenothrin & Deltamethrin & Permethrin & Fenitrothion \\
\hline
\end{tabular}


Table 2. LD50 and RR values of Musca domestica L. adults from 6 cities in Turkey

\begin{tabular}{|c|c|c|c|c|c|c|c|c|c|c|c|}
\hline \multirow[b]{2}{*}{ Strain } & \multirow{2}{*}{$\begin{array}{c}\text { Insecticides } \\
\text { Year }\end{array}$} & \multicolumn{2}{|c|}{ Cypermethrin } & \multicolumn{2}{|c|}{ Cyphenothrin } & \multicolumn{2}{|c|}{ Deltamethrin } & \multicolumn{2}{|c|}{ Permethrin } & \multicolumn{2}{|c|}{ Fenitrothion } \\
\hline & & $\mathrm{LD}_{50}$ & RR & $\mathrm{LD}_{50}$ & RR & $\mathrm{LD}_{50}$ & RR & $\mathrm{LD}_{50}$ & RR & $\mathrm{LD}_{50}$ & RR \\
\hline \multirow[t]{3}{*}{ Adana } & 2006 & 19.2 & 270.42 & 17.06 & 84.03 & 3.01 & 158.42 & 9.65 & 83.18 & 17.01 & 9.9 \\
\hline & 2005 & 15.17 & 213.66 & 14.08 & 69.35 & 2.17 & 114.21 & 5.78 & 49.82 & 18.98 & 11.05 \\
\hline & 2004 & 13.02 & 183.38 & 15.34 & 75.56 & 1.08 & 56.84 & 3.15 & 27.15 & 11.08 & 6.45 \\
\hline \multirow[t]{3}{*}{ Ankara } & 2006 & 13.01 & 183.23 & 37.27 & 183.59 & 2.96 & 155.78 & 13.55 & 116.81 & 28.33 & 16.49 \\
\hline & 2005 & 24.2 & 340.84 & 63.51 & 312.85 & 0.41 & 21.57 & 32.4 & 279.31 & 42.63 & 24.82 \\
\hline & 2004 & 20.07 & 282.67 & 66.17 & 325.96 & 1.27 & 66.84 & 17.25 & 148.7 & 36.48 & 21.24 \\
\hline \multirow[t]{3}{*}{ Antalya } & 2006 & 21.31 & 300.14 & 58.07 & 286.05 & 2.77 & 145.78 & 17.26 & 148.79 & 67.43 & 39.27 \\
\hline & 2005 & 60.49 & 851.97 & 55.68 & 274.28 & 2.25 & 118.42 & 20.03 & 172.67 & 77.12 & 44.91 \\
\hline & 2004 & 55.45 & 780.98 & 51.54 & 253.89 & 3.16 & 166.31 & 23.78 & 205 & 79.37 & 46.22 \\
\hline \multirow[t]{3}{*}{ İstanbul } & 2006 & 18.22 & 256.61 & 24.56 & 120.98 & 2.31 & 121.57 & 7.33 & 63.18 & 18.43 & 10.73 \\
\hline & 2005 & 20.36 & 286.76 & 53.79 & 264.97 & 1.34 & 70.52 & 15.87 & 136.81 & 44.87 & 26.13 \\
\hline & 2004 & 25.6 & 360.56 & 45.18 & 222.56 & 2.79 & 146.84 & 14.06 & 121.2 & 43.32 & 25.23 \\
\hline \multirow[t]{3}{*}{ İzmir } & 2006 & 3.74 & 52.77 & 43.65 & 215.02 & 5.58 & 293.68 & 9.56 & 82.41 & 50.71 & 29.53 \\
\hline & 2005 & 6.54 & 92.14 & 89.42 & 440.49 & 3.17 & 166.84 & 5.6 & 48.27 & 66.79 & 38.89 \\
\hline & 2004 & 8.75 & 123.23 & 70.66 & 348.07 & 4.3 & 226.31 & 9.1 & 78.44 & 78.8 & 45.89 \\
\hline \multirow[t]{3}{*}{ Şanlıurfa } & 2006 & 7.36 & 103.66 & 34.45 & 169.7 & 3.78 & 198.94 & 17.42 & 150.17 & 41.71 & 24.29 \\
\hline & 2005 & 2.76 & 38.95 & 4.4 & 21.71 & 0.73 & 38.42 & 4.28 & 36.89 & 76.49 & 44.54 \\
\hline & 2004 & 2.75 & 38.73 & 4.7 & 23.19 & 0.04 & 2.1 & 0.24 & 2.06 & 86.5 & 50.37 \\
\hline WHO & & 0.071 & 1 & 0.203 & 1 & 0.019 & 1 & 0.116 & 1 & 1.717 & 1 \\
\hline
\end{tabular}

\section{Bioassays}

Biological tests were performed according to the WHO standard residual surface methods $(13,14) .370 \mathrm{~mL}$ glass jars (insecticide application surface $270 \mathrm{~cm}^{2}$ ) were used for the application surface. Application doses were determined according to $\mathrm{WHO}$ recommendations and five serially $1 / 5$ diluted concentrations were used (15). Maximum concentrations of WHO recommendations are provided in Table 1. Five to seven day old females were used for tests and each tests consisted of four groups of 20 flies for each treatment level. Bioassays were conducted at $27 \pm 1^{\circ} \mathrm{C}$ and $65 \%$ relative humidity with a $12-\mathrm{h}$ photoperiod. Flies were transferred to insecticide free clear jars after a one hour application period. Moist cotton and sugar impregnated cotton were placed on the top of each jar and mortality was determined after 24 hours from treatment with insecticides.

\section{Data Evaluation}

LD values were defined with Probit Analysis (16) using the EPA probit analysis program version 1.3. Resistance ratios of field populations were calculated with the formula shown below. Resistance ratio of $\mathrm{WHO}$ susceptible strain was accepted as 1 .

$\mathrm{RR}=\mathrm{LD} 50$ of field populations/LD of WHO susceptible populations.

\section{RESULTS}

The results of the residual bioassays are shown in Table 2. The level of resistance of $M$. domestica $L$. for all treatment insecti- cides varied widely from year to year. However, fenitrothion resistance levels were lower than the pyrethroids used in this study. The change of resistance levels between years fluctuated greatly and was high for cypermethrin and cyphenothrin used in this study.

The highest resistance ratios were found in the Antalya strain (780.98 for 2004, 851.97 for 2005, 300.14 for 2006) for all years. Resistance levels decreased in all populations against cypermethrin from 2004-2006 except in Şanlıurfa and Adana strains (Table 2). The highest change of resistance level was determined in the Antalya strain from 2005 to 2006 (resistance level decreased).

Resistance levels increased in the Adana, Antalya and Şanlıurfa strains and decreased in the Ankara, Istanbul and Izmir strains against cyphenothrin (Table 2). The highest resistance ratios were recorded in the Izmir strain in the years 2004 (348.07 RR50) and 2005 (440.49 RR50) and in the Antalya strain in 2006 (286.05 RR50). The highest change of resistance level was found in the Sanliurfa strain from 2005 to 2006 (resistance level increased). Yearly changes in resistance ratios for the Adana and Antalya strains were very low from 2004 to 2006, but resistance ratios did increase gradually.

Resistance levels increased in all strains from 2004 to 2006 for deltamethrin except for the Antalya and Istanbul strains, but the resistance levels in these strains also increased from 2005 to 2006 (Table 2). The highest resistance ratios were found in the Izmir 
strain for all years, but levels decreased in 2005 and later increased again in 2006, even exceeding the 2004 levels. The highest changes in resistance ratios were found in the Şanlıurfa strain from 2005 to 2006.

Resistance levels increased for three strains (Adana, Izmir, Şanlıurfa) and decreased in others (Ankara, Antalya, İstanbul) from 2004 to 2006 for permethrin (Table 2). Yearly changes in resistance ratios were very low in the Adana, Antalya and Izmir strains from 2004 to 2006, but resistance ratios increased step by step in the Adana strain. In the Izmir strain however, resistance levels decreased in 2005 and later increased in 2006. In the Antalya strain resistance ratios decreased gradually. The highest resistance ratio was found in the Ankara strain (2005).

Fenitrothion resistance ratios were determined to be low for all populations tested in this study (Table 2). Resistance ratios decreased from 2004 to 2006 for all strains except in the Adana strain and resistance ratios varied around 6.45 (Adana 2004) to 50.37 (Şanlıurfa 2004). The lowest resistance ratios were found in the Adana strain in all years but resistance ratios increased nearly threefold from 2004 to 2006.

\section{DISCUSSION}

Previously, the resistance status of house flies in Turkey have been examined by different authors (17-23). Although they had shown low or high resistance level against all of the chemical insecticide groups, Cetin et al. (23) reported low levels of Insect Growth Regulators (IGRs) resistance for some strain in the Antalya region. In this study, we found high resistance levels in a three year period towards pyrethroid group insecticides. This insecticide group has been used in housefly and mosquito control applications since the late 1980's and today in Turkey control applications depend greatly on pyrethroid. Fenitrothion has been used in control applications since the 1980's as residual exposure but the usage of this insecticide has decreased since the 1990's (21).

Pyrethroid group insecticide resistance levels were very high. We determined a decreasing trend in the Antalya and Istanbul strains and an increasing trend in the Adana and Şanlıurfa strains for this insecticide from 2004 to 2006. The decreasing trend may be related to the collection area and insecticide application profile. In these areas where cow farms are prevalent, application frequencies are lower than other sites such as garbage areas. In addition to this situation, cyphenothrin and deltamethrin were only used in the Istanbul collection area. Although cypermethrin and cyphenothrin resistance showed a decreasing trend, deltamethrin and permethrin showed an increasing trend in the Izmir strain. Although deltamethrin, permethrin and cyphenothrin were used in the last ten years in this area, this situation may be related to the application frequencies of these insecticides, or yearly rotations of these insecticides. Except for permethrin, the same trend was also determined in the Ankara strain. Although we determined a decreasing trend, resistance ratios were still high. The high level of resistance in all strains is expected to be due to the extensive usage of this insecticide group. The degree of resistance to cypermethrin and cyphenothrin were higher than the other two insecticides. This situation can be related to the usage of cypermethrin and cyphenothrin in vector control programs conducted during the last ten years in this area. The observed situation in the Antalya strain cannot be explained by the above given scenario, because insecticides used in this study are not a part of the control applications conducted in this area.

Since the 1990's, Fenitrothion usage was very low in control applications and our results confirm this situation. Although fenitrothion resistance ratios were low, we were still able to record moderate levels of resistance and also a decreasing trend from 2004 to 2006 . This situation may be explained by usage of other organophosphate insecticide (Azametiphos for Ankara, Antalya, İstanbul and Şanlıurfa strain) in control applications.

A general examination of the data would seem to be indicating that resistance varies widely and is still high in all strains for pyrethroid group insecticides. Decreasing trends cannot be explained solely by insecticide usage. The sharpest decreasing trend was found for cypermethrin resistance in the Antalya strain and is not related to application profiles because cypermethrin has not been used in this area during the last ten years. Moreover, high resistance levels indicate that there are strong selection pressures on all populations. Chapman et al. (24), showed selective pressure and resistance development for all insecticides after three trials for deltamethrin, cypermethrin and permethrin. Fenitrothion resistance ratios varied around approximately 6-50 fold and these ratios were very low for all tested populations in this study compared to the pyrethroid group. This situation may reflect the non-usage of this compound for control operations. In addition to these results, our findings suggest that genes leading to organophosphate resistance are preserved in the tested populations. Fenitrothion usage seems to be appropriate for control operations, however resistance levels will likely increase, since intense usage is necessary to deal with the above situation.

House fly resistance to insecticides is a big problem in Turkey as it is globally. In recent years insecticide resistance surveys of $M$. domestica have been conducted in Turkey. Akiner et al. (21) reported high pyrethroid resistance in six different locations in Turkey and also found low levels of fenitrothion resistance. Cakir et al. (22) showed resistance against cypermethrin and deltamethrin and also reported the efficiency of piperonyl butoxide (PBO) and $\mathrm{PBO}+$ tetramethrin for house fly control in Turkey. Cetin et al. (23) determined low levels of IGRs resistance in house fly populations of five different southwestern Turkey.

Although there are many registered compounds for house fly and mosquito control, these compounds tested in this study are still being used by operators. Therefore high resistance can be predicted towards these products. Therefore, conventional insecticide usage must be restricted before resistance becomes a serious problem. Cetin et al. (23) also indicated the same problem and reported low levels of resistance towards IGRs. Although in recent years studies monitoring and measuring insecticide resistance are increasing, there is still a need for further monitoring efforts for the establishment of effective control programs covering all aspects of resistance development. 


\section{Conflict of Interest}

No conflict of interest was declared by the authors.

\section{REFERENCES}

1. Greenberg B. Flies and Disease. Vol. II Biology and Disease Transmission. Princeton: Princeton University Press; 1973.

2. Oliveira VC, D'Almeida JM, Abalem de Sá IV, Mandarino JR, Solari CA. Enterobacteria associated to adults of Musca domestica (Linnaeus, 1758) (Diptera:Muscidae) and Chrysomya megacephala (Fabricius, 1754) (Diptera: Calliphoridae) at the Zoo of Rio de Janeiro, Brazil. Arq. Bras. Med. Vet. Zootec. 2006; 58 (4) Belo Horizonte Aug.

3. Georghiou GP, Mellon RB. Pesticide resistance in time and space. Pest resistance to pesticides 1983; p. 1-46.

4. Scolt JG, Roush TR, Rutz DA. Insecticide resistance of house flies from new york dairies (Diptera: Muscidae). J Agric Enlomol 1989; 6: 53-64.

5. Tezok OF, Kilicturgay K, Toppare S, Ersoz N. Resistance tests which are performed with insecticides on house flies. Mikrobiyoloji Bülteni 1973; 7: 246-63.

6. Elyassaki WM. Resistance to pyrethroids in the housefly Musca domestica L. (Diptera Muscidae). Summary of Msc Thesis, USA 1986; http://www.clyassaki.4t.com/mscsum.html.

7. WHO (World Healt Organization). Vector control series. The housefly, training and information guide, intermediate level. World Health Organization, Geneva, 1986; WHO/VBC/90.987

8. WHO (World Healt Organization). Technical report series 818: Vector resistance to pesticides. World Health Organization, Geneva, 1992; 63 p.

9. Caglar SS, Akiner MM, Yazgan N. Resistance to organochlorine and pyrethroid insecticides in different populations of $\mathrm{M}$. domestica $\mathrm{L}$. (Diptera: Muscidae). Paper presented at 13th European Society for Vector Ecology Meeting, 24-29 September, Antalya, Turkey: 2000.

10. Kasai S, Scott JG. Overexpression of cytochrome P450 CYP6D1 is associated with monooxygenasemediated pyrethroid resistance in house flies from Georgia. Pest Biochem Physiol 2000; 68: 34-41. [CrossRef]

11. Kristensen M, Knorr M, Spencer AG, Jespersen JB. Selection and reversion of azamethiphosresistance in a field population of the housefly Musca domestica (Diptera: Muscidae), and the underlying biochemical mechanisms. J Econ Entomol 2000; 93: 1788-95. [CrossRef]

12. Kočišová A, Novák P, Toporčák J, Petrovský M. Development of resistance in field housefly (Musca domestica): comparison of effects classic spray regimes versus integrated control methods. Acta Vet Brno 2002; 71: 401-5. [CrossRef]
13. WHO (World Healt Organization). Criteria and meaning of tests for determining the susceptibility or resistance of insects to insecticides diagnostic test. World Health Organization, Geneva, 1981a; WHO/ $\mathrm{VBC} / 81.6 ., 4 \mathrm{p}$.

14. WHO (World Healt Organization). Instructions for determining the susceptibility or resistance of adult mosquitoes to organochlorine, organophosphate and carbamate insecticides-diagnostic test. World Health Organization, Geneva, 1981b; WHO/ VBC/81.806., 6 p.

15. Chavasse DC, Yap HH. Chemical methods for the control of vectors and pests of public health importance. World Health Organization; 1997.

16. Finney DJ. Probit Analysis. 3rd ed. Cambridge: Cambridge University Press, 1977.

17. Taylor RN. Insecticide resistance in houseflies from the Middle East and North Africa with notes on the use of various bioassay techniques. Pest Sci 1982; 13: 415-25. [CrossRef]

18. Sisli MN, Kocak O, Caglar SS, Eryilmaz A. Life table studies on the wild and susceptible populations of housefly, Musca domestica L. (Diptera: Muscidae) and the effects of malathion, fenitrothion and propoxur on these populations. Ulusal Çevre Sempozyumu Tebliğ Metinleri, 12-15 November, Adana, Turkey, 1984; p 817-24.

19. Sisli MN, Bosgelmez A, Kocak O, Porsuk H. The effect of malathion, fenitrothion and propoxur on the housefly, Musca domestica L. (Diptera: Muscidae) populations. Mikrobiyoloji Bulteni 1983; 17: 49-62.

20. Caglar SS. The investigation on resistance level to tetramethrin of housefly, Musca domestica L. (Diptera:Muscidae) and life table studies. Doga-Tr J Zool 1991; 15: 91-7.

21. Akiner MM, Caglar SS. The status and seasonal changes of organophosphate and pyrethroid resistance in Turkish populations of the house fly, Musca domestica L. (Diptera: Muscidae). Journal of Vector Ecology 2006; 31: 426-32. [CrossRef]

22. Cakir G, Yavuz O, Kocak O. Effects of Piperonyl Butoxide and Tetramethrin Combinations on Biological Activities of Selected Synthetic Pyrethroid Insecticides against Different Housefly (Musca domestica L., Diptera: Muscidae) Populations. Acta Vet Brno 2008; 77: 467-74. DOI:10.2754/avb200877030467 [CrossRef]

23. Cetin $H$, Erler F, Yanikoglu A. Survey of insect growth regulator (IGR) resistance in house flies (Musca domestica L.) from southwestern Turkey. Journal of Vector Ecology 2009; 34(2):329-337. DOl: 10.1111/j.1948-7134.2009.00042.x [CrossRef]

24. Chapman PA, Webb PP, Walker SJ. The potential of some newer photostable pyrethroids to select for resistance in the housefly Musca domestica (Diptera:Muscidae). Bull Entomol Res 1993; 83: 517-21. [CrossRef] 